\title{
Antibacterial activities of the methanol extracts of ten Cameroonian vegetables against Gram-negative multidrug-resistant bacteria
}

\author{
Jaurès AK Noumedem ${ }^{1,2}$, Marius Mihasan², Stephen T Lacmata' ${ }^{1}$ Marius Stefan², Jules R Kuiate ${ }^{1 *}$ and Victor Kuete ${ }^{1 *}$
}

\begin{abstract}
Background: Many edible plants are used in Cameroon since ancient time to control microbial infections. This study was designed at evaluating the antibacterial activities of the methanol extracts of ten Cameroonian vegetables against a panel of twenty nine Gram negative bacteria including multi-drug resistant (MDR) strains.

Methods: The broth microdilution method was used to determine the Minimal Inhibitory Concentrations (MIC) and the Minimal Bactericidal Concentrations (MBC) of the studied extracts. When chloramphenicol was used as a reference antibiotic, the MICs were also determined in the presence of Phenylalanine-Arginine $\beta$-Naphtylamide (PABN), an efflux pumps inhibitor (EPI). The phytochemical screening of the extracts was performed using standard methods.
\end{abstract}

Results: All tested extracts exhibited antibacterial activities, with the MIC values varying from 128 to $1024 \mathrm{mg} / \mathrm{L}$. The studied extracts showed large spectra of action, those from L. sativa, S. edule, C. pepo and S. nigrum being active on all the 29 bacterial strains tested meanwhile those from Amaranthus hybridus, Vernonia hymenolepsis, Lactuca.carpensis and Manihot esculenta were active on $96.55 \%$ of the strains used. The plant extracts were assessed for the presence of large classes of secondary metabolites: alkaloids, anthocyanins, anthraquinones, flavonoids, phenols, saponins, steroids, tannins and triterpenes. Each studied plant extract was found to contain compounds belonging to at least two of the above mentioned classes.

Conclusion: These results confirm the traditional claims and provide promising baseline information for the potential use of the tested vegetables in the fight against bacterial infections involving MDR phenotypes.

Keywords: Antibacterial, Gram-negative bacteria, Multi-drug resistant, Extract, Vegetable

\section{Background}

Infectious diseases are still a major health concern, accounting for $41 \%$ of the global disease burden measured in terms of Disability-Adjusted Life Years (DALYS), close to all noninfectious diseases (43\%) and far more than injuries (16\%) [1]. One of the main causes of this problem is the widespread emergence of acquired bacterial resistance to antibiotics in such a way that the world is facing today, a serious threat to global public health [2] in the form of not only epidemics, but also pandemics of antibiotic resistance [3]. Several mechanisms have been accounted for, but active efflux plays an important role in this

\footnotetext{
*Correspondence: jrkuiate@yahoo.com; kuetevictor@yahoo.fr

'Department of Biochemistry, Faculty of Science, University of Dschang, P.O.

Box 67, Dschang, Cameroon

Full list of author information is available at the end of the article
}

phenomenon [4]. The accumulation of different antibiotic resistance mechanisms within the same strains has led to the appearance of the so called superbugs, or multi-drug resistant bacteria [2]. Due to this problem of resistance to antibiotics, attention is now being shifted towards biologically active components isolated from plant species commonly used as herbal medicine, as they may offer a new source of antibacterial, antifungal and antiviral activities [5]. The potential antimicrobial properties of plants are related to their ability to synthesize several secondary metabolites of relatively complex structures possessing antimicrobial activities [6,7]. Among medicinal plants, vegetables associated to non or less-toxic effects have been shown to possess many medicinal properties $[8,9]$ including antibacterial effects [3]. The present work was therefore designed to investigate the antibacterial effects of ten

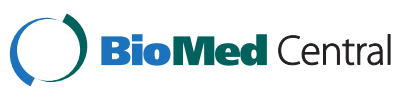


Cameroonian vegetables namely Amarantus hybridus Linn (Amarantaceae), Vernonia hymenolepis (H.F.) Hook., Lactuca sativa Linn. and Lactuca capensis Thumb. (Asteraceae), Manihot esculenta Crantz (Euphorbiaceae), Phaseolus vulgaris Linn (Fabaceae), Cucurbita pepo Linn and Sechium edule (Jacq) Sw. (Cucurbitaceae), Solanum nigrum Linn. and Capsicum frutescens L. (Solanaceae) against MDR bacteria expressing active efflux pumps

\section{Methods}

\section{Plant material and extraction}

The collected plant materials used in this study were harvested from Dschang, West Region of Cameroon in June 2010 and included the leaves of Amarathus hybridus, Vernonia hymenolepis, Lactuca sativa, Lactuca capensis, Sechium edule, Manihot esculenta, Curcubiata pepo, Solanum nigrum, the cloves of the Green bean (Phaseolus vulgaris), and the fruits of Capsicum frutescens. These plants were identified by Mr Victor Nana of the National Herbarium (Yaoundé-Cameroon) where all the voucher specimens were deposited with the corresponding reference number (Table 1 ).

Air dried and powdered sample $(1 \mathrm{~kg})$ of each plant was extracted with methanol $(\mathrm{MeOH})$ for $48 \mathrm{~h}$ at room temperature $\left(25^{\circ} \mathrm{C}\right)$, using Whatman Grade No.1 filter paper and concentrated under reduced pressure, then dried to give the crude extracts. All extracts were stored at $4^{\circ} \mathrm{C}$ until further use.

\section{Preliminary phytochemical investigations}

The major secondary metabolites classes such as alkaloids, anthocyanins, anthraquinones, flavonoids, phenols, saponins, tannins, sterols and triterpenes were screened according to the common phytochemical methods previously described by Harbone, 1973 [70].

\section{Bacterial strains and culture media}

The studied bacteria included both reference (from the American Type Culture Collection) and clinical strains of Providencia stuartii, Pseudomonas aeruginosa, $K$. pneumoniae, Escherichia coli, Enterobacter aerogenes and Enterobacter cloacae (See Additional file 1: Table S1 for their features). These clinical strains were obtained from the laboratory "Transporteurs Membranaires, Chimiorésistance et Drug Design, UMR-MD1, IFR 88, UFRs de Médecine et de Pharmacie, Marseille, France". All strains were maintained in Nutrient Broth at $4{ }^{\circ} \mathrm{C}$ and activated on Mueller Hinton Agar plates $24 \mathrm{~h}$ prior to any antimicrobial test. Mueller Hinton Broth (MHB) was used for all antibacterial assays.

\section{Bacterial susceptibility testing}

The MICs were determined using the rapid INT colorimetric assay $[71,72]$. Briefly, test samples were first emulsified in DMSO/MHB (50:50 V/V). The solution obtained was then added to $\mathrm{MHB}$, and serially diluted two fold (in a 96- wells microplate). One hundred microlitres $(100 \mu \mathrm{l})$ of inoculum $\left(1.5 \times 10^{6} \mathrm{CFU} / \mathrm{ml}\right)$ prepared in MHB was then added. The plate was covered with a sterile plate sealer, then agitated to mix the contents of the wells using a shaker and incubated at $37^{\circ} \mathrm{C}$ for $18 \mathrm{~h}$. The final concentration of DMSO was $2.5 \%$ and did not affected the microbial growth. Wells containing MHB, $100 \mu \mathrm{l}$ of inoculum and DMSO at a final concentration of $2.5 \%$ served as negative control. The MICs of samples were detected after $18 \mathrm{~h}$ incubation at $37^{\circ} \mathrm{C}$, following addition of $40 \mu \mathrm{l}$ of a $0.2 \mathrm{mg} / \mathrm{ml}$ INT solution and incubation at $37^{\circ} \mathrm{C}$ for 30 minutes. Viable bacteria reduce this yellow dye to pink. MIC was defined as the lowest sample concentration that exhibited complete inhibition of microbial growth and then prevented this change [73]. The MBC was determined by adding $50 \mu \mathrm{L}$ of the suspensions from the wells, which did not show any growth after incubation during MIC assays, to $150 \mu \mathrm{L}$ of fresh broth. These suspensions were re-incubated at $37^{\circ} \mathrm{C}$ for 48 hours. The $\mathrm{MBC}$ was determined as the lowest concentration of extract which completely inhibited the growth of bacteria [74].

Chloramphenicol, used as reference antibiotic, was tested also in the presence of the PA $\beta \mathrm{N}$, at $30 \mathrm{mg} / \mathrm{L}$ final concentration to confirm the resistance of bacterial strains.

\section{Results}

\section{Chemical composition of the vegetable extracts}

The results of the qualitative analysis showed that each of the studied plant extract contains at least two classes of secondary metabolites such as alkaloids, anthocyanins, anthraquinones, flavonoids, phenols, saponins, steroids, tannins and triterpenes (Table 2). Only the extract from A. hybridus contains anthocyanins, while triterpenes were found both in this extract as well as that of C. frutescens. The extract from $C$. frutescens as well as those from S. edule and $M$. esculenta contained the highest number of classes of the studied secondary metabolites (five). Alkaloids and phenols were present in all vegetable extracts except that of A. hybridus.

\section{Antibacterial activity of the vegetable extracts}

The data summarized in Table 3 show the antibacterial activities of the tested extracts on a panel of twenty-nine Gram-negative bacteria. All extracts were active on at least twelve bacterial strains with $\mathrm{MIC} \leq 1024 \mu \mathrm{g} / \mathrm{ml}$. The extract of $C$. frutescens showed inhibitory activities against 16 (55.17\%) of the 29 tested bacteria whilst that of $P$. vulgaris inhibited the growth of $12 / 29$ (41.38\%) pathogens (narrowest spectrum). None of these two extracts showed any antibacterial activity against Pseudomonas species, but were active against at least one bacterial strain of other studied genus. Extracts from L. sativa, S. edule, C. pepo 
and S. nigrum displayed the largest spectra of activity, their inhibitory effects being observed on all the $29 \mathrm{Gam}$ negative bacteria (100\% of activity). The extracts from $A$. hybridus, $V$. hymenolepis, $L$. sativa, $L$. carpensis and $M$. esculenta also exhibited large spectrum of activity as they were active on $28 / 29$ tested bacteria. The top eight active extracts, with large spectra of activity, showed MIC values generally ranging from 128 to $512 \mu \mathrm{g} / \mathrm{ml}$. These MIC values were in some of the cases better than those of choramplenicol (Table 3). This was the case with the extract from $V$. hymenolepis (MIC of $128 \mu \mathrm{g} / \mathrm{ml}$ ) against $E$. aerogenes EA27. The extracts from A. hybridus, S. edule and $C$. pepo as well as those from $L$. capensis and $M$. esculenta were more active than chloramphenicol on at least one of the tested MDR bacteria. The activity of chloramphenicol increased in the presence of PA $\beta \mathrm{N}$ in the majority of the tested bacteria (Table 3 ). The best activity was obtained with the extract from $A$. hybridus with the lowest MIC value of $128 \mu \mathrm{g} / \mathrm{ml}$ observed against 7/29 (25\%) tested bacteria. The extracts from $P$. vulgaris and $C$. frutescens did not show any MBC value at up to $1024 \mu \mathrm{g} / \mathrm{ml}$. Concering the eight other vegetable extracts, the $\mathrm{MBC}$ results showed values equal to or below $1024 \mu \mathrm{g} / \mathrm{ml}$ in many cases. The extract from C. pepo leaves showed the best $\mathrm{MBC}$ spectrum with the values below to $1024 \mu \mathrm{g} / \mathrm{ml}$ recorded on 58,62\% (17/29) of the studied microorganisms, followed by those from M. esculenta leaves on $51,72 \%$ (15/29), A. hybridus, V. hymenolepis and L. capensis extracts on $44.83 \%(13 / 29)$ and L. sativa on $31.03 \%(9 / 29)$ (Table 4).

Table 4 also shows that $M$. esculenta exhibited MBC values against all the strains of $E$. aerogenes and that, in general, the extracts showed values which were not 4-fold greater than the corresponding MICs.

\section{Discussion}

In plants, secondary metabolites attract beneficial and repel harmful organisms, serve as phytoprotectants and respond to environmental changes. In animals, such compounds have many beneficial effects including antibacterial and antiviral properties [75,76]. The classes of secondary metabolites detected in the tested vegetables can somehow provide a prelimanry explanation on their activities [77]. In general, the phytochemical contents (Table 2) were in accordance with the previous reports for some of the vegetables where data were available $[11,12,23,38]$. It should however be mentioned that the detection of the bioactive phytochemical classes in a plant is not a guarantee for any biological property, as this will depend on the types of compounds, as well as their concentrations and possible interaction with other constituents.

Solanum nigrum has been shown to possess various activities such as antitumorigenic, antioxidant, anti- inflammatory, hepatoprotective diuretic and antipyretic [63]. Though the exact mechanism of action remains to be elucidated in many cases, few are known about its antibacterial properties. In fact, it has been shown that seeds of $S$. nigrum possess good antimicrobial activity against E. coli on solid medium [63]. We report herein for the first time the antibacterial activity of leaves methanol extract of this plant against a panel of MDR Gram-negative bacterial strains with MIC values varying from 128 to $1024 \mu \mathrm{g} / \mathrm{ml}$ (Table 3). Solanum nigrum possesses various compounds that are responsible for diverse activities. Among these compounds, solanine (found in all parts of the plant [58]),is its major defence product [58].

Many reports have also been published about the biological properties of C. pepo, but these reports are based on the components of the fruits and the seed's oil $[54,55,57,78]$. To the best of our knowledge, were herein report for the first time its activities against MDR bacteria.

The results of the phytochemical test on $P$. vulgaris are in accordance with some other reports [48,79]. Phaseolus vulgaris was found to inhibit also the growth of Grampositive bacteria B.subtilis [49]. Amarowicz et al. [80] showed that the acetone extract of $P$. vulgaris contains tannins with good antimicrobial properties against Listeria monocytogenes. Therefore, the low antibacterial effects of this plant as obtained herein (generally MIC values at $1024 \mu \mathrm{g} / \mathrm{ml}$ ) (Table 3) could be due to the multi-drug resistance ability of the studied bacteria.

The antibacterial effects of the extract from $C$. frutescens against Staphylococcus aureus as well as K. pneumoniae and $P$. aeruginosa have been reported [67]. The ethanol extract of this plant was also active against MDR strains of S. aureus [81]. The present study therefore provides additional information on the antibacterial potential of this plant on MDR Gram-negative bacteria with MICs ranging from 256 to $024 \mu \mathrm{g} / \mathrm{ml}$.

The antibacterial properties of S. edule have already been proved against bacteria of clinical relevance by Ordonez et al. [41] which showed that both fluid extract and tincture of fruits have "very good" antimicrobial activities against MDR staphylococci and enterococci [41]. Herein, the antimicrobial activity of the leaves extract \{known to possess high level of secondary metabolites and mostly flavonoids [39]\} observed against all the studied bacterial strains (Table 3) is being reported for the first time.

The chloroform extract of $M$. esculenta possess antibacterial activities against Listeria monocytogenes, Vibrio cholerae, Shigella flexneri and Salmonella typhi whilst ethanol extract was found active against $P$. aeruginosa, Corynebacterium diphtheriae and V. cholera [46]. This report provides additional data on antibacterial activity 
Table 1 Plant species used in this study and their reported effects

\begin{tabular}{|c|c|c|c|c|}
\hline $\begin{array}{l}\text { Plant (family); } \\
\text { and voucher } \\
\text { number }^{\mathrm{a}}\end{array}$ & Traditional uses & $\begin{array}{l}\text { Parts used } \\
\text { traditionally }\end{array}$ & $\begin{array}{l}\text { Bioactive or potentially bioactive } \\
\text { components }\end{array}$ & $\begin{array}{l}\text { Bioactivities of extracts and/or } \\
\text { compounds }\end{array}$ \\
\hline $\begin{array}{l}\text { Amarantus } \\
\text { hybridus Linn } \\
\text { (Amarantaceae); } \\
15630 \text { HNC }\end{array}$ & $\begin{array}{l}\text { intestinal bleeding, diarrhoea and } \\
\text { excessive menstruation }[5,10]\end{array}$ & $\begin{array}{l}\text { Leaves, } \\
\text { seeds }\end{array}$ & $\begin{array}{l}\text { flavonoids, steroids, terpenoids, } \\
\text { cardiac glycosides [5] alkaloid, saponin, } \\
\text { tannins, phenols, hydrocyanic acid } \\
\text { and phytic acid }[11,12]\end{array}$ & antimicrobial [5,13] \\
\hline $\begin{array}{l}\text { Vernonia } \\
\text { calvoana (H.F.) } \\
\text { Hook } \\
\text { (Asteraceae); } \\
42401 / \text { HNC }\end{array}$ & $\begin{array}{l}\text { wounds [14],anticancer [15], fever, } \\
\text { stomach ache, diarrhoea, hernia, } \\
\text { spleen enlargement [16] }\end{array}$ & leaves & $\begin{array}{l}\text { vernolepin [17,18], vernomenin [18], } \\
\text { flavonoids (quercetin, apigenin, } \\
\text { luteolin) [19] }\end{array}$ & $\begin{array}{l}\text { cytotoxic [17], spasmolytic, anti- } \\
\text { aggregating and de-aggregating } \\
\text { activities, } 2 \text { antitumor activity, } \\
\text { antimicrobial [20], insecticide [21], } \\
\text { antifilarial [22] }\end{array}$ \\
\hline $\begin{array}{l}\text { Lactuca sativa } \\
\text { Linn; } \\
\text { (Asteraceae); } \\
\text { 25624/SRF.Cam }\end{array}$ & $\begin{array}{l}\text { analgesic, conjunctivitis, tired eyes, } \\
\text { Insomnia, sedative [23] insomnia, } \\
\text { anxiety, neurosis, dry coughs, } \\
\text { rheumatic pain [24] stimulate } \\
\text { digestion, enhance appetite and } \\
\text { relieve inflammation [25] }\end{array}$ & leaves & $\begin{array}{l}\text { phenolic acids, triterpenoids, } \\
\text { saponins, phytol [23], carotenoids } \\
\text { [26], flavonoids including kaempherol } \\
\text { [19] Lettucenin-A guaianolide } \\
\text { sesquiterpenelactones conjugates, } \\
\text { lactucin, deoxylactucin and } \\
\text { lactucopicrin [27] }\end{array}$ & $\begin{array}{l}\text { antimicrobial [28], antifungal, } \\
\text { antibacterial [29], antitumor [30] } \\
\text { antioxidating, analgesic, and anti- } \\
\text { inflammatory [23] depressant [31] } \\
\text { sedative, hypnotic, analgesic and } \\
\text { anticonvulsant [32] hypoglycaemic } \\
\text { [33] antioxidant I [34,35], and } \\
\text { anxiolytic }\end{array}$ \\
\hline
\end{tabular}

Lactuca capensis

Thumb

(Asteraceae);

27743 HNC

Sechium edule

(Jacq) SW

(Cucurbitaceae):

42459/HNC

Manihot esculenta Crantz

(Euphorbiaceae); 57650/HNC

Phaseolus

vulgaris Linn

(Fabaceae);

42587/HNC

Cucurbita pepo

Linn

(cucurbitaceae): antispasmodic, digestive, diuretic, hypnotic, narcotic and sedative properties. treatment of insomnia, anxiety, neuroses, hyperactivity in children, dry coughs, whooping cough, rheumatic pain, chronic join pains [36]

urine retention, kidney diseases, arteriosclerosis, hypertension [38]

hypertension, headache and pain, irritable bowel syndrome. fever headache, aches and pains [44]

osteoporosis prevention, diuretic, eczema, antiglycemic [47]

intestinal infections and kidney problems (seeds), minor injuries (flowers), anthelmintic, hypertension, erysipelas, enteritis, dyspepsia, stomach disorders, liver disorders like leaves

lactucarium, sesquiterpene lactone [37] 15630 HNC jaundice [50]

leaves

leaves

cloves

Solanum nigrum

Linn

(Solanaceae);

43000 HNC pneumonia aching teeth, stomache ache, tonsilitis, tonic,wing worms [14], pain, inflammation and fever. tumor, antioxydant, antiinflammatory, hepaprotective, diuretic, antipyretic [58]
C-glycosyl and O-glycosyl, flavones in roots, leaves, stem and fruits [39], ascorbic acid,gibberellins, flavonoids and saponins [38]

3-rutinosides of kaempferol and quercetin; the cyanogenic glycosides, lotaustralin and linamarin, from the fresh leaves of cassava [45]

ascorbic acid, phenol, alkaloids, sterols, saponins (aqueous extract), carotenoids like lutein, $\beta$-carotene, violanthin and neoxanthin, flavonoids [48] including quercetin, kaemferol, catechins, epicatechins and procyanidins

saponin, tannin, quinone, coumarins, flavonoids, sterol, terpenes, [51] lignin, alkaloids, protein and sugar Curbicin [52] anthocyanin, phenols like syringic acid [52], phytin, lecithin, cucurbitane and hexanocucurbitane L-2-O- $\beta$-glucopyranoside, Curbicin [52], flavonoids, Vitamins $B, C$, and $E$, $\beta$-sitostérol

kaempferol [19,59] terpenoids and condensed tannin [60], quercetin flavonoids [19], polysaccharides, polyphenolic compounds including galic acid, catechin, cafeic acid, rutin and naringenin [58] diuretic [9], free radical-scavenger and antioxydant [40],antibacterial [41], antihypertensive [42] hepatoprotective activity of ethanolic extract and its different [43]

anthelmintic activity of crude extracts antibacterial [46]

antioxydant [48], antibacterial [49]

antihypertensive, anti-oxidative activities,Arthritis, reduce the symptoms of BPH [52,53]. High Cholesterol, anti-parasitic activity in vi-vitro [54], alleviates the detrimental effects associated with protein malnutrition [55], antiparasitic[56], nephron and hepato-protective, vermifuge, inhibitor of prostaglandin biosynthesis [57], antiparasitic, protects gastric mucosal [50]

anti-inflammatory, antioxidant, anthelmintic activity [60] antinociceptive, antipyretic, antitumor, antiulcerogenic, cancer chemopreventive, hepatoprotective, and immunomodulatory effects [61] Mosquito larvicidal [62], antibacterial [63] 


\section{Table 1 Plant species used in this study and their reported effects (Continued)}

\begin{tabular}{ll}
\hline Capsicum & wound, male virility [16], insecticide fruits \\
frutescens L. & [64], rheumatism, laxative [65] relieve \\
(Solanaceae); & muscle, joint, and toothache pain, to \\
10737/SRFcam & treat cough, asthma, and sore throat, \\
& as a stimulant, treat stomach ache, \\
& seasickness, and flatulence anciently
\end{tabular}

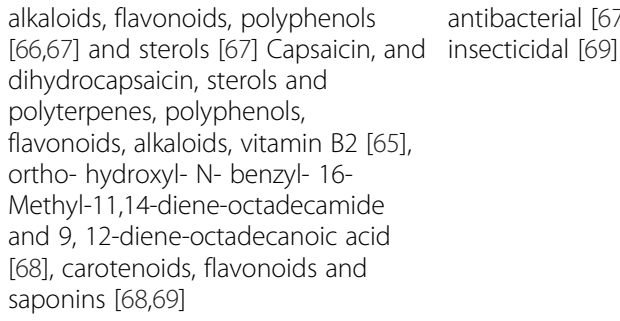

a(HNC): Cameroon National Herbarium; (SRFC): Société des Réserves Forestières du Cameroun.

of $M$. esculenta against MDR strains of P. aeruginosa, E. coli, E. cloacae, K. pneumoniae, P stuartii and E. aeorogenes. The activity of Amaranthus hybridus was reported against E. coli, S. typhi, K. pneumoniae and $P$. aeruginosa with MICs ranged between 200 and $755 \mathrm{mg} / \mathrm{ml}$ [5]. The ethyl acetate extract exhibited activity against $S$. aureus and B. subtilis whilst the ethanol extract was found effective against E.coli [13].

The high MIC values observed with chloramphenicol can be explained only if we take into account the nonspecific resistance mechanism: active efflux of the toxic compound by pumps belonging to the small multidrug resistance (SMR) proteins family [4]. The fact that the efflux pump inhibitor $(\mathrm{PA} \beta \mathrm{N})$ enhances the chloramphenicol antibacterial properties is a clear indication that the tested strains express an active efflux system and that this system is responsible for resistance of the tested bacteria to chloramphenicol. The wide substrate specificity of these pumps, as well as their widespread among bacterial species make us believe that these efflux pumps are also responsible for the extrusion of various active compounds from the plant extract out of bacteria cells, therefore preventing their inhibitory effects. Therefore, the activities of the vegetable as observed herein against MDR strains (with MIC comprised between 128 and $1024 \mu \mathrm{g} / \mathrm{mL}$ ) could be considered important, especially when considering the fact that we are dealing with edible plants. Apart for the extracts of P. vulgaris and C. frutescens which did not show any MBC below $1024 \mu \mathrm{g} / \mathrm{ml}$, other values further confirmed the bactericidal effect of the 8 remaining extracts as they were generally less than 4-fold greater than corresponding $\mathrm{MIC}$ values $[82,83]$.

\section{Conclusions}

The overall results of the present investigation confirmed the traditional uses of the studied vegetables in the treatment of bacterial infections. This study also provide baseline information for the possible use of the methanol extracts of the tested plant samples in the control of infectious diseases involving Gram-negative MDR bacteria. The arising question is of course which are the active compounds responsible for these effects. Our research group is currently focusing on the characterization of these plants extracts in terms of chemical composition and synergistic effects.

Table 2 Extraction yields and phytochemical composition of the plant extracts

\begin{tabular}{|c|c|c|c|c|c|c|c|c|c|c|c|}
\hline $\begin{array}{l}\text { Scientific } \\
\text { names }\end{array}$ & $\begin{array}{l}\text { Part } \\
\text { used }\end{array}$ & $\begin{array}{l}\text { Yield } \\
(\%)\end{array}$ & alkaloids & phenols & tannins & terpènes & stéroids & flavonoids & anthraquinones & anthocyanins & saponins \\
\hline $\begin{array}{l}\text { Amarantus } \\
\text { hybridus }\end{array}$ & leaves & 7.9 & - & - & - & + & - & + & - & + & - \\
\hline $\begin{array}{l}\text { Vernonia } \\
\text { hymenolepis }\end{array}$ & leaves & 9.40 & + & + & - & - & - & + & - & - & - \\
\hline Lactuca sativa & leaves & 7.14 & + & + & - & - & - & + & - & - & - \\
\hline Lactuca capensis & leaves & 7.14 & + & + & + & - & + & - & - & - & - \\
\hline Sechium edule & leaves & 3.76 & + & + & - & + & + & + & - & - & + \\
\hline Manihot esculinta & leaves & 07.46 & + & + & + & + & + & + & + & - & + \\
\hline $\begin{array}{l}\text { Phaseolus } \\
\text { vulgaris }\end{array}$ & cloves & 17.81 & + & + & - & - & + & + & - & - & - \\
\hline Cucurbita pepo & leaves & 12.68 & + & + & - & - & + & + & - & - & - \\
\hline solanum nigrum & leaves & 11.84 & + & + & - & - & + & + & - & - & - \\
\hline $\begin{array}{l}\text { Capsicum } \\
\text { frutescens }\end{array}$ & fruits & 16.24 & + & + & - & + & - & + & + & - & - \\
\hline
\end{tabular}

(+): Present; (-): Absent; *The yield was calculated as the ratio of the mass of the obtained methanol extract/mass of the plant powder. 
Table 3 Susceptibility of bacteria to plant extracts - MICs of methanol extracts vs chloramphenicol

\begin{tabular}{|c|c|c|c|c|c|c|c|c|c|c|c|}
\hline \multirow[t]{2}{*}{ Bacteria strains } & \multicolumn{11}{|c|}{ MIC $(\mu \mathrm{g} / \mathrm{ml})$ of the plant extracts } \\
\hline & $\begin{array}{l}\text { A. } \\
\text { hybridus }\end{array}$ & $\begin{array}{l}V . \\
\text { hymenolepis }\end{array}$ & $\begin{array}{l}\text { L. } \\
\text { sativa }\end{array}$ & $\begin{array}{l}\text { L. } \\
\text { capensis }\end{array}$ & $\begin{array}{l}\text { S. } \\
\text { edule }\end{array}$ & $\begin{array}{l}\text { M. } \\
\text { esculenta }\end{array}$ & $\begin{array}{l}P . \\
\text { vulgaris }\end{array}$ & $\begin{array}{l}\text { C. } \\
\text { pepo }\end{array}$ & $\begin{array}{l}\text { S. } \\
\text { nigrum }\end{array}$ & $\begin{array}{l}\text { C. } \\
\text { frutescens }\end{array}$ & Chloramphenicol $^{1}$ \\
\hline \multicolumn{12}{|l|}{ E. coli } \\
\hline ATCC8739 & 256 & 1024 & 512 & 512 & 256 & 256 & 1024 & 512 & 512 & 512 & 4 \\
\hline ATCC10536 & 128 & 256 & 128 & 256 & 128 & 256 & - & 256 & 128 & - & 4 \\
\hline W3110 & 256 & 512 & 256 & 256 & 256 & 512 & - & 128 & 256 & - & $8(<2)$ \\
\hline MC4100 & 512 & 1024 & 512 & 1024 & 256 & 512 & 1024 & 256 & 512 & 1024 & $16(<2)$ \\
\hline AG100A & 256 & 512 & 512 & 512 & 256 & 512 & - & 512 & 512 & 1024 & $<2(<2)$ \\
\hline AG100Atet & 256 & 512 & 512 & 512 & 256 & 512 & - & 512 & 512 & 1024 & $64(<2)$ \\
\hline AG102 & 1024 & 128 & 1024 & 512 & 512 & 128 & - & - & 256 & 512 & $64(<2)$ \\
\hline AG100 & 128 & 1024 & 128 & 512 & 512 & 512 & - & 256 & 128 & - & $8(<2)$ \\
\hline \multicolumn{12}{|l|}{ E. aerogenes } \\
\hline ATCC13048 & 128 & 1024 & 256 & 256 & 256 & 256 & 1024 & 256 & 256 & - & 8 \\
\hline EA294 & 512 & 512 & 512 & 512 & 512 & 1024 & - & 512 & 512 & 1024 & 16 \\
\hline CM64 & 128 & 128 & 256 & 256 & 128 & 256 & 1024 & 512 & 256 & 512 & 256 (8) \\
\hline EA3 & 256 & 256 & 128 & 128 & 256 & 128 & 1024 & 128 & 128 & - & $256(128)$ \\
\hline EA298 & 256 & 512 & 256 & 256 & 256 & 256 & 1024 & 128 & 256 & 1024 & $64(<2)$ \\
\hline EA27 & 512 & 128 & 256 & - & 512 & 512 & - & 512 & 256 & 512 & $\geq 256(<2)$ \\
\hline EA289 & - & 512 & 1024 & 256 & 512 & 256 & 1024 & 128 & 1024 & 256 & $\geq 256(64)$ \\
\hline \multicolumn{12}{|l|}{ K. pneumoniae } \\
\hline ATCC11296 & 256 & 512 & 256 & 512 & 512 & 512 & 512 & 256 & 256 & - & 8 \\
\hline KP55 & 256 & 512 & 256 & 512 & 256 & 512 & 1024 & 256 & 256 & 256 & $32(4)$ \\
\hline KP63 & 256 & 256 & 256 & 256 & 256 & 256 & - & 512 & 256 & 512 & $64(<2)$ \\
\hline $\mathrm{K} 2$ & 512 & - & 512 & 512 & 1024 & 512 & - & 1024 & 512 & 1024 & $32(<2)$ \\
\hline K24 & 512 & 1024 & 512 & 512 & 512 & - & 1024 & 512 & 512 & 1024 & $16(<2)$ \\
\hline \multicolumn{12}{|l|}{ P. aeruginosa } \\
\hline PA01 & 256 & 512 & 512 & 256 & 256 & 512 & - & 256 & 512 & - & 16 \\
\hline PA124 & 512 & 1024 & 512 & 512 & 512 & 512 & - & 512 & 512 & - & $32(<2)$ \\
\hline \multicolumn{12}{|l|}{ P. stuartii } \\
\hline ATCC29916 & 128 & 128 & 256 & 1024 & 128 & 1024 & - & 1024 & 256 & - & 16 \\
\hline NAE16 & 128 & 512 & 256 & 256 & 256 & 256 & 1024 & 512 & 256 & - & $64(8)$ \\
\hline PS2636 & 512 & 512 & 256 & 256 & 256 & 256 & - & 256 & 256 & 512 & 32 \\
\hline PS299645 & 512 & 1024 & 1024 & 512 & 512 & 512 & - & 512 & 1024 & - & $32(<2)$ \\
\hline \multicolumn{12}{|l|}{ E. cloacae } \\
\hline BM47 & 128 & 256 & 512 & 1024 & 256 & 1024 & - & 128 & 512 & - & $\geq 256(<2)$ \\
\hline ECCI69 & 256 & 512 & 512 & 256 & 256 & 128 & - & 256 & 512 & - & $\geq 256(16)$ \\
\hline BM67 & 256 & 512 & 512 & 256 & 256 & 512 & 1024 & 128 & 512 & 1024 & $128(32)$ \\
\hline
\end{tabular}

The results are shown as average values from three separate experiments.

$(-) \mathrm{MIC}>1024 \mu \mathrm{g} / \mathrm{ml}$.

1 - chloramphenicol was used as a reference antibiotic. MIC was measured in absence and presence of PABN (in brackets). 
Table 4 Susceptibility of bacteria to plant extracts - MBCs $(\mu \mathrm{g} / \mathrm{ml})$ of methanol extracts vs chloramphenicol

\begin{tabular}{|c|c|c|c|c|c|c|c|c|c|c|c|}
\hline Bacteria strains & $\begin{array}{l}\text { A. } \\
\text { hybridus }\end{array}$ & $\begin{array}{l}V . \\
\text { hymenolepis }\end{array}$ & $\begin{array}{l}\text { L. } \\
\text { sativa }\end{array}$ & $\begin{array}{l}\text { L. } \\
\text { capensis }\end{array}$ & $\begin{array}{l}\text { S. } \\
\text { edule }\end{array}$ & $\begin{array}{l}\text { M. } \\
\text { esculenta }\end{array}$ & $\begin{array}{l}\text { Green bean } \\
\text { (P. vulgaris) }\end{array}$ & $\begin{array}{l}\text { C. } \\
\text { pepo }\end{array}$ & $\begin{array}{l}\text { S. } \\
\text { nigrum }\end{array}$ & $\begin{array}{l}\text { C. } \\
\text { frutescens }\end{array}$ & Chloramphenicol $^{1}$ \\
\hline \multicolumn{12}{|l|}{ E. coli } \\
\hline ATCC8739 & - & - & - & - & 1024 & 1024 & - & 512 & - & - & 64 \\
\hline ATCC10536 & 1024 & - & - & - & - & - & - & 1024 & - & - & 128 \\
\hline W3110 & 1024 & 512 & 256 & - & 512 & - & - & 512 & - & - & - \\
\hline MC4100 & 1024 & - & - & - & - & - & - & - & - & - & - \\
\hline AG100A & - & 1024 & 512 & - & - & 512 & - & - & - & - & - \\
\hline AG100Atet & - & 1024 & 512 & - & - & - & - & - & - & - & - \\
\hline AG102 & - & - & 512 & 1024 & - & - & - & - & - & - & - \\
\hline AG100 & 256 & 1024 & - & 1024 & - & 512 & - & 1024 & - & - & - \\
\hline E. aerogenes & - & - & - & & - & & & & 512 & & \\
\hline ATCC13048 & & & & 1024 & & 1024 & - & 1024 & & - & 128 \\
\hline EA294 & - & - & - & - & - & 1024 & - & - & - & - & 32 \\
\hline CM64 & 512 & - & - & 512 & 512 & 512 & - & - & - & - & - \\
\hline EA3 & 1024 & 512 & 1024 & 1024 & - & 512 & - & 1024 & 1024 & - & - \\
\hline EA298 & 512 & 1024 & 1024 & - & 1024 & 256 & - & 256 & 512 & - & - \\
\hline EA27 & - & - & - & - & - & 512 & - & - & - & - & - \\
\hline EA289 & - & 1024 & - & 512 & 1024 & 512 & - & - & - & - & - \\
\hline \multicolumn{12}{|l|}{ K. pneumoniae- } \\
\hline ATCC11296 & - & - & - & 1024 & - & - & - & 256 & 1024 & - & 64 \\
\hline KP55 & 1024 & - & - & - & 1024 & 1024 & - & 1024 & 512 & - & 128 \\
\hline KP63 & 512 & 512 & - & - & - & - & - & 512 & 1024 & - & - \\
\hline $\mathrm{K} 2$ & 1024 & - & - & 1024 & - & - & - & - & - & - & 256 \\
\hline K24 & - & - & - & - & 1024 & - & - & 512 & - & - & 512 \\
\hline \multicolumn{12}{|l|}{ P. aeruginosa } \\
\hline PA01 & - & - & - & - & - & - & - & - & - & - & 256 \\
\hline PA124 & - & 1024 & - & 1024 & - & - & - & 1024 & 512 & - & - \\
\hline \multicolumn{12}{|l|}{ P. stuartii } \\
\hline ATCC29916 & - & 256 & - & 1024 & 1024 & 1024 & - & 1024 & 512 & - & 128 \\
\hline NAE16 & - & - & 512 & - & 1024 & - & - & 1024 & - & - & 256 \\
\hline PS2636 & 512 & & 1024 & 1024 & - & 1024 & - & 512 & - & - & - \\
\hline PS299645 & - & - & - & - & - & - & - & - & - & - & - \\
\hline \multicolumn{12}{|l|}{ E. cloacae } \\
\hline BM47 & - & 1024 & 512 & - & - & - & - & - & 1024 & - & - \\
\hline $\mathrm{ECCl} 69$ & 1024 & 512 & - & 1024 & 512 & 1024 & - & 1024 & 512 & - & - \\
\hline BM67 & 512 & 1024 & - & 1024 & 1024 & 1024 & - & 1024 & - & - & - \\
\hline
\end{tabular}

The results are shown as average values from three separate experiments.

$(-) \mathrm{MBC}>1024 \mu \mathrm{g} / \mathrm{ml}$.

1 - chloramphenicol was used as a reference antibiotic. 


\section{Additional file}

Additional file 1: Table S1. Bacterial strains and features.

\section{Competing interest}

The authors declare that they have no competing interest.

\section{Authors' contributions}

JAKN, MM, STL and MS carried out the study; VK designed the experiments. JAKN, MM and VK wrote the manuscript; VK and JRK supervised the work; VK provided the bacterial strains; all authors read and approved the final manuscript.

\section{Acknowledgements}

Authors are thankful to Prof. Dumitru Cojocaru (University Alexandru loan Cuza, lasi-Romania), the Romanian Government and The Agence Universitaire de la Francophonie for travel grant to JAKN, and also to Professor Jean-Marie Pages (through VK), Chair of the UMR-MD1 Unit, Université de la Méditerranée, France for providing us with MDR bacteria.

\section{Author details}

${ }^{1}$ Department of Biochemistry, Faculty of Science, University of Dschang, P.O. Box 67, Dschang, Cameroon. ${ }^{2}$ Department of Biochemistry and Molecular Biology, Faculty of Biology, Alexandru loan Cuza University, lasi, Romania.

Received: 28 September 2012 Accepted: 28 January 2013 Published: 31 January 2013

\section{References}

1. NIE 99-17D NIE: The global infectious disease threat and its implications for the United States. 2000, http://www.heart-intl.net/HEART/072404/. accessed on August 12, 2012.

2. Chopra I: New drugs for superbugs. Microbiology Today 2000, 47:4-6.

3. Chanda S, Baravalia Y, Kaneria M, Rakholiya K: Fruit and vegetable peels strong natural source of antimicrobics. In Current research, technology and education topics in apllied microbiology and microbial biotechnology. Edited by Mendez-Vilas A. Badajoz, Spain: Formatex; 2010.

4. Pages J-M, Lavigne J-P, Leflon-Guibout V, Marcon E, Bert F, Noussair L, Nicolas-Chanoine M-H: Efflux pump, the masked side of ß-Lactam resistance in Klebsiella pneumoniae clinical isolates. PLOS ONE 2009, 4:e4817.

5. Maiyo ZC, Ngure RM, Matasyoh JC, Chepkorir R: Phytochemical constituents and antimicrobial activity of leaf extracts of three Amaranthus plant species. Afr J Biotechnol 2010, 9:3178-3182.

6. Matasyoh JC, Maiyo ZC, Ngure RM, Chepkorir R: Chemical composition and antimicrobial activity of the essential oil of Coriandrum sativum. J Food Chem 2009, 113:526-529.

7. Evarando LS, Oliveira LE, Freire LKR, Sousa PC: Inhibitory action of some essential oils and phytochemicals on growth of various moulds isolated from foods. Braz Arch Biol Technol 2005, 48:234-241.

8. Hedges $\sqcup$, Lister CE: Nutritional attributes of some exotic and lesser known vegetables. In Plant \& Food Research Confidential Report No. 2325. Edited by Report PFRC, vol. 2325 Christchurch. New Zealand Institute for Plant \& Food Research Limited; 2009.

9. Dhiman K, Gupta A, Sharma DK, Gill NS, Goyal K: A review on the medicinal important plants of the family of Cucurbitaceae. Asian J Clin Nutr 2012, 4:16-26.

10. He HP, Corke H, Cai JG: Supercritical carbon dioxide extraction of oil and squalene from Amaranthus Grain. J Agr Food Chem 2003, 51:7921-7925.

11. Akubugwo IE, Obasi NA, Chinyere GC, Ugbogu AE: Nutritional and chemical value of Amaranthus hybridus L. leaves from Afikpo Nigeria. Afr J Biotechnol 2007, 6(24):2833-2839.

12. Akubugwo IE, Obasi NA, Chinyere GC, Ugbogu AE: Mineral and phytochemical contents in leaves of Amaranthus hybridus $L$ and Solanum nigrum L. subjected to different processing methods. Afr J Biochem Res 2008, 2:040-044.

13. Dahiya SS, Sheoran SS, Sharma SK: Antibacterial activity of Amaranthus hybridus linn. root extracts. IJABPT 2010, 1:46-49.
14. leCAB2010: Contribution of agriculture to achieving MDGs. In Contribution of Agricultural Sciences towards achieving the Millenium Development Goals. Edited by Mwangi M. Kenya: Nairobi, FaCT Publishing; 2010.

15. Rajwar S, Khatri P, Patel R, Dwivedi S, Dwivedi A: An overview on potent herbal anticancer drugs. Int J Res Pharm Chem 2011, 1:202-210.

16. Hamisy WC, Mwaseba D, Zilihona IE, Mwihomeke ST: Status and domestication potential of medicinal plants in the Uluguru mountain area, Tanzania. Morogoro: Tanzania: Wildlife Conservation Society of Tanzania (WCST); 2000:55.

17. Perdue REJ, Carlson KD, G GM: Vernonia galamensis, potential new crop source of epoxy acid I. Econ Bot 1986, 40:54-68.

18. Sims RJ: Synthesis of furanosesquiterpenoid natural products. Southampton: University Of Southampton; 1981.

19. Yang R-Y, Lin S, Kuo G: Content and distribution of flavonoids among 91 edible plant species. Asia Pac J Clin Nutr 2008, 17(S1):275-279.

20. Barrero AF, Oltra JE, Barragán A, Álvarez M: Approaches to the synthesis of 8-epi-vernolepin from germacrolides. J Chem Soc 1998, 1:4107-4113.

21. Fane S: Etude de la toxicite de certaines plantes vendues sur les marches du district de Bamako, Doctorat d'état. Bamako: Université de Bamako; 2003.

22. Bhanu Prasad K, Avinash Kumar RG, Jyothi MJ, Rasheed A, Dalith D: Natural antifilarial drugs: a review. International Journal of Pharmacology and Toxicology 2011, 1:1-10.

23. Rodrigues E, Tabach R, Galduróz JCF, Negri G: Plants with possible anxiolytic and/or hypnotic effects indicated by three Brazilian cultures Indians, afro-Brazilians, and river-dwellers. Stud Nat Prod Chem 2008, 35:549-595.

24. Katz SH, Weaver WW: Encyclopidia of food and culture. New York: In. schribner Ed; 2003.

25. Sayyah M, Hadidi N, Kamalinejad M: Analgesic and anti-inflammatory activity of Lactuca sativa seed extract in rats. J Ethnopharmacol 2004, 92:325-329.

26. Cruz R, Baptista P, Cunha S, Pereira JA, Casal S: Carotenoids of lettuce (lactuca sativa L.) grown on soil enriched with spent coffee grounds. Molecules 2012, 17:1535-1547.

27. Van Beek TA, Mass P, King BM, Laclercq E, Voragen AGJ, de Groot A: Bitter sesquiterpene lactones from chicory roots. J Agr Food Chem 1990, 38:1035-1038.

28. Brandi G, Amagliani G, Schiavano GF, De Santi M, Sisti M: Activity of Brassica oleracea leaf juice on foodborne pathogenic bacteria. J Food Prot 2006, 69(9):2274-2279.

29. Bennett MH, Gallagher MDS, Bestwick CS, Rossiter JT, Mansfield JW: The phytoalexin response of lettuce to challenge by Botrytis cinerea, Bremialactucae and Pseudomonassyringae pv.phaseolicola. Physiol Mol, Plant Pathol 1994, 44:321-333.

30. Ye X-J, Ng T-B, Wu Z-J, Xie L-H, Fang E-F, Wong J-H, Pan W-L, Wing S-S-C, Zhang Y-B: Protein from red cabbage (Brassica oleracea) Seeds with antifungal, antibacterial, and anticancer activities. J Agr Food Chem 2011, 59:10232-10238.

31. Gonzalex LF, Valedon A, Stiehil WL: Depressant pharmacological effects of component isolated from lettuce, lactuca sativa. Int J Crude Drug Res 1996, 24:154.

32. Sid SA, El-Kashef H, El Mazes, Slam OMM: Phytochemical and pharmacological studies on Lactuca sativa seed oil. Fitoterapia 1996, 67:215-219.

33. Roman RR, Flores S-J, Alarcon AFJ: Anti-hyperglycaemic effect of some edible plants. J Ethnopharmacol 1995, 48:25-32.

34. Garg M, Garg C, Mukherjee Pulok K, Suresh B: Antioxidant potential of Lactuca sativa. Ancient Sci Life 2004, 24(1):1-4.

35. Patil RB, Vora SR, Pillai MM: Antioxidant effect of plant extracts on phospholipids levels in oxidatively stressed male reproductive organs in mice. Iran J Rep Med 2009, 7:35-39.

36. Wambugu SN, Mathiu PM, Gakuya DW, Kanui TI, Kabasa JD, Kiama SG: Medicinal plants used in the management of chronic joint pains in Machakos and Makueni counties, Kenya. J Ethnopharmacol 2011, 137:945-955

37. Michalska K, Stojakowska A, Malarz J, Doležalová I, Lebeda A, Kisiel W: Systematic implications of sesquiterpene lactones in Lactuca species. Biochem Syst Ecol 2009, 37:174-179.

38. Albone KS, Skin PG: Identification and localization of gibberilins in maturing seed of cucurbit Sechium edule. Planta 1984, 162:560-565. 
39. Siciliano T, De Tommasi N, Morelli I, Braca A: Study of flavonoids of Sechium edule (Jacq) swartz (Cucurbitaceae) different edible organs by liquid chromatography photodiode array mass spectrometry. J Agr Food Chem 2004, 52:6510-6515.

40. Ordonez AAL, Gomez JD, Vattuone MA, Isla Ml: Antioxidant activities of Sechium edule (Jacq.) Swartz extracts. Food Chem 2006, 97:452-458.

41. Ordoñez AAL, Gomez JD, Cudmani NM, Vattuone MA, Isla MI: Antimicrobial Activity of Nine Extracts of Sechium edule (Jacq.) Swartz. Microb Ecol Health Dis 2003, 15:33-39.

42. Gordon EA: The antihypertensive effects of the Jamaican cho-cho. W Indian Med J 2000, 1:27-31.

43. Firdous SM: Protective effect of ethanolic extract and its ethylacetate and $\mathrm{n}$-butanol fractions of Sechium edule fruits against paracetamol induced hepatic injury in mice. Asian J Pharm Clin Res 2012, 5:10-14.

44. Abd Aziz SM, Low CN, Chai LC, Abd Razak SSN, Selamat J, Son R, Sarker MZI, Khatib A: Screening of selected Malaysian plants against several food borne pathogen bacteria. Int Food Res J 2011, 18:1195-1201.

45. Suresh R, Saravanakumar M, Suganyadevi P: Anthocyanins from indian cassava (manihot esculenta crantz) and its antioxidant properties. Int Food Res J 2011, 18:1195-1201.

46. Zakaria ZA, Khairi HM, Somchit MN, Sulaiman MR, Mat Jais AM, Reezal I, Mat Zaid NN, Abdul Wahab SNZ, Fadzil NS, Abdullah M, Fatimah CA: The in vitro antibacterial activity and brine shrimp toxicity of Manihot esculenta var. Sri Pontian extracts. Int J Pharmacol 2006, 2:216-220.

47. The Health Benefits of Green Beans. http://www.elements4health.com/ green-beans.html, Accessed on July, 12, 2012.

48. Doss A, Pugualenthi M: Evaluation of antioxydant activity and phytochemical screening of Malus domestica Borkh (apple) and Phaseolus vulgaris L. (green beans). Journal of Pharmaceutical and Scientific Innovation 2012, 3:1-4.

49. Chaurasia S, Saxena R: Antibacterial Activity of Four Different Varieties of Green Beans. Res J Pharm Biol Che Sci 2012, 3:70-74.

50. Sarkar S, Guha D: Effect of ripe fruit pulp extract of Cucurbita pepo Linn. in aspirin induced gastric and duodenal ulcer in rats. Indian J Exp Biol 2008, 46:639-645.

51. Karpagam T, Varalakshmi B, Bai JS, Gomathi S: Effect of different doses of Cucurbita pepo linn extract as an anti-Inflammatory and analgesic nutraceautical agent on inflamed rats. IJPRD 2011, 3:184-192.

52. Carbin BE, Larsson B, Lindahl O: Treatment of benign prostatic hyperplasia with phytosterols. B J Urol 1990, 66:639-641.

53. Carbin BE, Eliasson R: Treatment by curbicin in benign prostatic hyperplasia (BPH). Swed J Biol Med 1989, 2:7-9.

54. al-Zuhair $\mathrm{H}$, Abd el-Fattah AA, el Latif HA A: Efficacy of Simvastatin and pumpkin-seed oil in the management of dietary-induced hypercholesterolemia. Pharmacol Res 1997, 3:403-408.

55. Nkosi CZ, Opoku AR, Terblanche SE: Effect of pumpkin seed (Cucurbita pepo) protein isolate on the activity levels of certain plasma enzymes in CCl4-induced liver injury in low-protein fed rats. Phytother Res 2005, 19:341-345

56. Sharma LD, Bagha HS, Srivastava PS: In vitro anthelmintic screening of indigenous medicinal plants against Haemonchus contortus (Rudolphi, 1803) Cobbold, 1898 of sheep and goats. Indian J Anim Resour 1971, 5:33-38.

57. Adepoju GKA, Adebanjo AA: Effect of consumption of Cucurbita pepo seeds on haematological and biochemical parameters. Afr J Pharm Pharacol 2011, 5:18-22.

58. Jain RAS, Gupta SSPI, Gabrani R: Solanum nigrum: current perspectives on therapeutic properties. Altern Med Rev 2011, 16:78-85.

59. Calderón-Montaño JM, Burgos-Morón E, Pérez-Guerrero C, López-Lázaro M: A review on the dietary flavonoid kaempferol. Mini Rev Med Chem 2011, 11:298-344.

60. Marie-Magdeleine C, Udino L, Philibert L, Bocage B, Archimede H: In vitro effects of Cassava (Manihot esculenta) leaf extracts on four development stages of Haemonchus contortus. Vet Parasitol 2010, 173:85-92.

61. Cai X, Chin Y, Oh S, Kwon O, Ahn K, Lee H: Anti-inflammatory constituents from Solanum nigrum. B Korean Chem Soc 2010, 31:199-201.

62. Rawani A, Ghosh A, Chandra G: Mosquito larvicidal activities of Solanum nigrum L. leaf extract against Culex quinquefasciatus Say. Parasitol Res 2010, 107:1235-1240.

63. Kumar S, Bagchi GD, Darokar MP: Antibacterial activity observed in the seeds of some Coprophilous plants. Int J Pharmacogn 1997, 35:179-184
64. Ndomo AF, Tapondjou1 AL, Tendonkeng F, F MT: Evaluation des propriétés insecticides des feuilles de Callistemon viminalis (Myrtaceae) contre les adultes d'Acanthoscelidesobtectus (Say) (Coleoptera; Bruchidae). Tropicultura 2009, 27:137-143.

65. N'Guessan K, Kadja B, Zirihi GN, Traoré D, L A-A: Screening phytochimique de quelques plantes médicinales ivoiriennes utilisées en pays Krobou (Agboville, Côte-d'Ivoire). Sciences and Nature 2009, 6:1-15.

66. Howard LR, Talcott ST, Brenes CH, Villalon B: Changes in phytochemical and antioxidant activity of selected pepper cultivars (Capsicum Species) as influenced by maturity. J Agr Food Chem 2000, 48:1713-1720.

67. Koffi-Nevrya RK, Nangabc KC, Koussémona ZY, Loukoubc GY: Antibacterial activity of two bell pepper extracts: Capsicum annuum $L$ and Capsicum frutescens. Int J Food Prop 2012, 15:961-971.

68. Dastagir MG, Husaain MM, Masum Billah AHM, Ismail M, Quader A: Phytochemical studies on Capsicum frutescens. IJPSDR 2012, 3(5):1507-1510.

69. Bouchelta A, Boughdad A, Blenzar A: Effets biocides des alcaloïdes, des saponines et des flavonoïdes extraits de Capsicum frutescens $L$. (Solanaceae) sur Bemisia tabaci (Gennadius) (Homoptera: Aleyrodidae). Biotechnol Agron Soc Environ 2005, 9:259-269.

70. Harbone JB: Phytochemical methods: a guide to modern techniques of plant analysis. London: Chapman \& Hall; 1973.

71. Eloff JN: A sensitive and quick microplate method to determine the minimal inhibitory concentration of plant extracts for bacteria. Planta Med 1998, 64:711-713.

72. Mativandlela SPN, Lall N, Meyer JJM: Antibacterial, antifungal and antitubercular activity of Pelargonium reniforme (CURT) and Pelargonium sidoides (DC) (Geraniaceae) root extracts. S Afr J Bot 2006, 72:232-237.

73. Kuete V, Ngameni B, Simo CCF, Tankeu RK, Ngadjui BT, Meyer JJM, Lall N, Kuiate JR: Antimicrobial activity of the crude extracts and compounds from Ficus chlamydocarpa and Ficus cordata (Moraceae). J Ethnopharmacol 2008, 120:17-24.

74. Cohen MA, Huband MD, Yoder SL, Gage JW, Roland GE: Bacterial eradication by clinafloxacin, $\mathrm{Cl}-990$, and ciprofloxacin employing MBC test, in-vitro time-kill and in-vivo time-kill studies. J Antimicrob Chemother 1998, 41:605-614.

75. Cowan MM: Plant products as antimicrobial agents. Clin Microbio/ Rev 1999, 12:564-582.

76. Kuete V: Potential of cameroonian plants and derived products against microbial infections: a review. Planta Med 2010, 76:1479-1491.

77. Voukeng IK, Kuete V, Fankam AG, Dzoyem JP, Noumedem JAK, Kuiate J-R, Pages J-M: Antibacterial and antibiotic-potentiation activities af the methanol extract of some Cameroonian spices against Gram-negative multi-drug resistant phenotypes. BMC Res Notes 2012, 5:299.

78. Sharma A, Kumar M, Kaur S: Modulatory effects of Syzygium aromaticum (L.) Merr. \& Perry and Cinnamomum tamala Nees \& Ebrem. on toxicity induced by chromium trioxide. Phytopharmacology 2011, 1:71-81.

79. Barkat M, Kadri F: Impact de deux modes de cuisson sur la teneur en polyphénols solubles de six légumes. Revue de génie industriel 2011, 6:41-45.

80. Amarowicz R, Dykes GA, B PR: Antibacterial activity of tannin constituents from Phaseolus vulgaris, Fagoypyrum esculentum, Corylus avellana and Juglans nigra. Fitoterapia 2008, 79:217-219.

81. Shariati A, Pordeli HR, Khademian A, Aydani M: Evaluation of the antibacterial effects of Capsicum spp. extracts on the Multi-resistant Staphylococcus aureus strains. J Plant Sci Res 2010, 17:10-16.

82. Carbonnelle B, Denis F, Marmonier A, Pinon G, Vague R: Bactériologie médicale: Techniques usuelles. Paris: SIMEP ed; 1987.

83. Mbaveng AT, Ngameni B, Kuete V, Simo KI, Ambassa P, Roy R, Bezabih M, Etoa F-X, Ngajui TB, Abegaz BM, Meyer JJ, Lall N, Beng VP: Antimicrobial activity of the crude extracts and five flavonoids from the twigs of Dorstenia barteri (Maraceae). J Ethnopharmacol 2008, 116:483-489.

\section{doi:10.1186/1472-6882-13-26}

Cite this article as: Noumedem et al:: Antibacterial activities of the methanol extracts of ten Cameroonian vegetables against

Gram-negative multidrug-resistant bacteria. BMC Complementary and Alternative Medicine 2013 13:26. 